\title{
Sistem Pendukung Keputusan Pemberian Bantuan Kepada Keluarga Kurang Mampu Menggunakan Metode AHP
}

\author{
Bobby Gersonta Ginting ${ }^{1 *}$, Fricles A. Sianturi² \\ ${ }^{1,2}$ STMIK Pelita Nusantara \\ Jl. Iskandar Muda No. 1 Medan 20154 Indonesia \\ Corresponding author's e-mail: bobbygersonta21@gmail.com
}

\begin{abstract}
Abstrak - Kemiskinan merupakan permasalahan yang masih dihadapi oleh beberapa negara-negara di dunia, khususnya di Indonesia. Kemiskinan merupakan suatu keadaan/kondisi ketidak mampuan individu/kelompok masyarakat untuk memenuhi kebutuhan hidup, baik kondisi fisik maupun ekonomi. Sistem pemberian bantuan yang dilakukan oleh Dinas Sosial Provinsi Sumatera Utara dengan metode Analytical Hierarchy Process. Metode yang digunakan dalam sistem pemberian bantuan ini metode Analytical Hierarchy Process di Dinas Sosial Provinsi Sumatera Utara. Hasil keputusan dari asumsi dalam pembobotan untuk setiap kriteria bersifat relatif. Kriteria-kriteria yang digunakan dalam penentuan penerimaan bantuan yaitu kriteria pekerjaan, kriteria penghasilan, kriteria konsumsi gizi (ayam, daging, susu), kriteria sumber penerangan, kriteria kemampuan berobat, kriteria pendidikan terahkir kepala keluarga. Metode yang digunakan dalam penelitian ini adalah metode AHP. Metode AHP adalah salah satu metode yang dipakai dalam Sistem Pendukung Keputusan penentuan pemberian bantuan ini adalah Analitical Hierarchy Process (AHP). Setelah mendapatkan nilai index konsistensinya, maka selanjutnya mencari nilai rasio konsistensi (CR) dengan membagi indeks konsistensi dengan indeks random konsistensi $(\mathrm{RI})$ yaitu $\mathrm{CR}=\mathrm{C} 1 / \mathrm{R} 1 \mathrm{CR}=0.09975 / 1.24=0.0891$, syarat untuk konsistensi $\mathrm{CR}<0.1$ maka nilai CR yang di dapat dari perbandingan diatas sudah konsisten.

Kata kunci: SPK. bantuan,rasio konsistensi, metode AHP
\end{abstract}

Abstract - Poverty is a problem that is still faced by several countries in the world, especially in Indonesia. Poverty is a condition / condition of the inability of individuals / groups of people to meet the necessities of life, both physical and economic conditions. The system of providing assistance carried out by the Social Service of North Sumatra Province uses the Analytical Hierarchy Process method. The method used in this aid system is the Analytical Hierarchy Process method in the Social Service of North Sumatra Province. The results of the weighted assumptions for each criterion are relative in nature. The criteria used in determining the receipt of assistance are job criteria, income criteria, nutritional consumption criteria (chicken, meat, milk), criteria for sources of information, criteria for medical ability, criteria for the last education of the head of the family. The method used in this research is the AHP method. AHP method is one of the methods used in the Decision Support System to determine the provision of this assistance is the Analytical Hierarchy Process (AHP). After getting the consistency index value, then look for the consistency ratio value (CR) by dividing the consistency index by the consistency random index $(\mathrm{RI})$, namely $\mathrm{CR}=\mathrm{C} 1 / \mathrm{R} 1 \mathrm{CR}=0.09975 / 1.24=0.0891$, the requirement for consistency $\mathrm{CR}<0.1$ then the $\mathrm{CR}$ value that is obtained from the comparison above it is consistent.

Keywords: SPK. assistance, consistency ratio, AHP method

\section{Pendahuluan}

Kemiskinan disebabkan oleh beberapa faktor salah satunya yaitu SDM yang kurang memadai. Hal ini, karena masyarakat miskin cenderung memiliki pendidikan yang sangat rendah, sehingga tidak mampu bersaing yang pada akhirnya menjadi pengangguran. Salah satu Kota yang masih memiliki permasalahan mengenai kemiskinan yaitu Kota Medan. Peran dari pemerintah sangat diperlukan, mengingat kebijakan dan peraturan yang dibuat menjadi acuan dalam mendorong kearah pembangunan. Program-program mengenai atasi kemiskinan, dimulai oleh pemerintah dengan menerbitkan Peraturan Presiden Republik Indonesia Nomor 15 Tahun 2010, tentang Percepatan Penanggulangan Kemiskinan. Dari diterbitkannya Peraturan Presiden tersebut, maka dibentuklah Tim Nasional Percepatan Penanggulangan Kemiskinan (TNP2K) ditingkat pusat, yang keaggotaannya terdiri dari unsur pemerintah, masyarakat, dunia usaha, dan pemangku kepentingan lainnya. Selanjutnya, di tingkat provinsi dan kabupaten/kota, dibentuk Tim Koordinasi Penanggulangan Kemiskinan Provinsi dan Kabupaten/Kota. Pada saat ini, telah banyak program-program yang dikeluarkan oleh pemerintah yang bertujuan untuk meningkatkan kesehatan, pendidikan, ekonomi, dan mengurangi beban masyarakat dalam pemenuhan kebutuhan hidup, termasuk pada dinas sosial.

Sistem pendukung keputusan merupakan bagian dari sistem informasi berbasis komputer yang mengatasi 
masalah yang saya identifikasi ini[1]. Sistem ini dapat mendukung pengambilan keputusan calon penerima bantuan pangan non tunai berdasarkan kriteria-kriteria yang telah ditentukan [2]. Cara kerja sistem ini mencakup seluruh tahap pengambilan masalah, memilih data yang relevan dan menentukan pendekatan yang digunakan dalam proses pengambilan keputusan sampai pemecahan dan solusi masalah [3].

Penelitian Sistem Pendukung Keputusan Untuk Menentukan Penerima BLSM Di Kabupaten Indramayu menjelaskan Penelitian ini dilatarbelakangi oleh banyaknya kasus yang menyatakan bahwa penyaluran BLSM tidak tepat sasaran, ada BLSM yang diperuntukkan bagi masyarakat tidak mampu secara ekonomi, namun terkadang masih ada masyarakat kaya yang juga menerimanya khususnya di kabupaten Indramayu, hal tersebut menyulitkan pihak penyeleksi dalam mengadakan penyeleksian calon penerima dana BLSM ini untuk itu dibuat sistem pendukung keputusan dalam menentukan penerima BLSM di kabupaten Indramayu dengan menggunakan metode Analytic Hierarchy Process (AHP) [4]. Penelitian Sistem Pendukung Keputusan Penerima Bantuan Langsung Tunai (BLT) Tepat Sasaran Menggunakan Metode AHP dan K-Means menjelaskan Jadi untuk mengetahui siapa yang benar-benar layak maka dibutuhkan sebuah sistem pengambilan keputusan agar penyetoran BLT dari pemerintah bisa tepat sasaran sesuai dengan kriteria yang ditetapkan oleh pemerintah. Tahapan penelitian dimulai dengan klastering terhadap bobot. Setelah itu dimasukkan ke dalam sistem untuk dilakukan proses pendukung keputusan dengan AHP [5]. Target penelitian ini berupa aplikasi yang dapat digunakan untuk membantu pemerintah dalam menyalurkan BLT tepat sasaran.Berdasarkan pengujian fungsional sistem yang telah dilakukan fungsi-fungsi dalam sistem ini telah berjalan sesuai perencanaan [6].

\section{Tinjauan Pustaka}

2.1 Sistem Pendukung Keputusan

Sistem merupakan komponen-komponen yang saling terkait, yang bekerjasama untuk mencapai suatu tujuan dengan menerima masukan dan menghasilkan keluaran dalam suatu proses transformasi yang tersusun secara teratur [7]. Setiap sistem merupakan bagian dari sistem yang lebih besar dan terdiri dari berbagai sistem yang lebih kecil, yang disebut sub sistem. Suatu sistem pada dasarnya adalah suatu susunan yang teratur dari kegiatan yang berhubungan satu sama lain dan prosedur yang berkaitan dan memudahkan pelaksanaan kegiatan utama dari suatu organisasi [8]. Sistem pendukung keputusan didefinisikan sebagai sistem informasi pada level manajemen dari suatu organisasi yang mengkombinasikan data dan model analisis canggih atau peralatan data analisis untuk mendukung pengambilan yang semi terstruktur dan tidak terstruktur [9].

\subsection{Analytical Hierarchy Process (AHP)}

AHP (Analitycal Hierarchy Process) adalah suatu teori umum tentang pengukuran yang digunakan untuk menemukan skala rasio, baik dari perbandingan berpasangan yang diskrit maupun kontinyu [10]. AHP menguraikan masalah multi faktor atau multi kriteria yang kompleks menjadi suatu hirarki. Hirarki didefinisikan sebagai suatu representasi dari sebuah permasalahan yang kompleks dalam suatu struktur multi level dimana level pertama adalah tujuan, yang diikuti level faktor, kriteria, sub kriteria, dan seterusnya ke bawah hingga level terakhir dari alternatif. Dengan hirarki, suatu masalah yang kompleks dapat diuraikan ke dalam kelompok-kelompoknya yang kemudian diatur menjadi suatu bentuk hirarki sehingga permasalahan akan tampak lebih terstuktur dan sistematis [11] [12].

\section{Metode Penelitian}

Metode penelitian penerapan metode Analytical Hierarchy Process (AHP) :

1. Analisa Masalah

Merupakan sekumpulan kegiatan, aktivitas dan proses yang saling berkaitan untuk memecahkan masalah atau memecahkan komponen menjadi lebih detail dan digabungkan kembali lalu ditarik kesimpulan.

2. Pengumpulan data

Merupakan kegiatan mencari data di lapangan yang akan digunakan untuk menjawab permasalahan penelitian. Validitas instrumen pengumpulan data serta kualifikasi pengumpul data sangat diperlukan untuk memperoleh data yang berkualitas.

3. Analisis Data

Ialah upaya atau cara untuk mengolah data menjadi informasi sehingga karakteristik data tersebut bisa dipahami dan bermanfaat untuk solusi permasalahan.

4. Proses Metode AHP

suatu metode pengambilan keputusan dengan melakukan perbandingan berpasangan antara kriteria pilihan dan juga perbandingan berpasangan antara pilihan yang ada.

5. Perancangan Pembangunan Sistem 
Desain sistem menentukan bagaimana suatu sistem akan menyelesaikan apa yang mesti diselesaikan, tahap ini menyangkut mengkonfigurasikan dari komponen-komponen perangkat lunak dan perangkat keras dari suatu sistem sehingga setelah instalasi dari sistem akan benar benar memuaskan rancang bangun yang telah ditetapkan pada akhir analisis sistem.

6. Implementasi Sistem

Ttahap penerapan sistem yang akan dilakukan jika sistem disetujui termasuk program yang telah dibuat pada tahap perancangan sistem agar siap untuk dioperasikan.

7. Pengujian Sistem

Pengujian program perangkat lunak yang lengkap dan terintegrasi. Biasanya, perangkat lunak dihubungkan dengan perangkat lunak dan perangkat keras lainnya.

\section{Hasil dan Pembahasan}

Dalam analisa sistem baru proses yang pertama kali dilakukan adalah sebagai berikut:

1. Menginputkan alternatif yang akan di bandingkan kemudian melakukan pembobotan dengan melihat nilai kepentingan berdasarkan kriteria-kriteria yang ditetapkan menggunakan metode AHP sehingga mendapatkan nilai eigen dari setiap kriteria.

2. Kemudian untuk hasil akhir akan menghasilkan penerima bantuan mana yang akan menjadiprioritas.Membangun sebuah sistem perlu melalui tahap analisa dan perancangan sehingga sistem yang dibangun dapat berjalan sesuai yang diharapkan. Dalam pembuatan sistem pendukung penerima bantuan ini berbasis web dengan bahasa PHP. Analisa data yang Ada 5 kriteria penilaian, terdiri dari :

a. Pekerjaan

Pekerjaan salah satu kriteria dalam menentukan penerimaan bantuan. Kapasitas ideal untuk penerima bantuan adalah jenis pekerjaaan. Rasio yang tidak sesuai akan tidak sesuai digunakan untuk menerima bantuan. Berdasarkan data yang didapat dari dinas sosial provinsi sumatera utara terdapat 5 jenis pekerjaan calon penerima bantuan. Dimana buruh dan petani sebagai yang dipriorits kan untuk menerima bantuan tersebut. (sumber: Dinsos Prov Sumut).

b. Penghasilan

Penghasilan merupakan salah satu kriteria yang dinilai dalam penentuan penerima bantuan. Dalam penelitian penghasilan dilihat dari jumlah penghasilan perbulan yang didapat Rp. $500.000-1.500 .000 \mathrm{Rp}$. 1.600.000 - 2.500.000 Rp. 2.600.000 - 3.500.000 Rp. 3.600.000 - 4.500.000 Rp. 4.600.000 - 5.500.000.

Kelima penghasilan yang dinilai memiliki kepentingan yang sama dan dalam pembagian tingkat penerima keseluruhan dibagi dalam 3 yaitu Penerima bantuan utama (66\%-100\%), Penerima bantuan dalam evaluasi (36\%-65\%), Tidak menerima bantuan (0\%-35\%).

c. Konsumsi Gizi/Bulan (Daging, Susu dan Ayam)

Konsumsi Gizi/bulan (Daging, Susu dan Ayam) merupakan salah satu dari kriteria penilaian yang dilakukan, Konsumsi Gizi/Bulan berpengaruh kepada penerima bantuan.

d. Sumber penerangan

Sumber penerangan merupakan salah satu kriteria dalam menentukan prioritas penerima bantuan. Dalam pembagian tingkat peneriman bantuan dibagi dalam 3 yaitu penerima bantuan utama, penerima bantuan dalam evaluasi, tidak menerima bantuan.

a. Kemampuan Berobat

Pembagian tingkat kemampuan berobat dibagi menjadi 3 yaitu Penerima bantuan utama, Penerima bantuan dalam evaluasi dan Tidak menerima bantuan.

Berikut ini adalah tahapan dalam menyelesaikan kasus dengan menggunakan metode $A H P$ untuk rekomendasi penerima bantuan.

1. Mencari Nilai Eigen Dengan Metode AHP

Dalam penyelesaian metode $A H P$ ada beberapa langkah yang harus dilakukan diantaranya yaitu :

a. Mendifinisikan masalah dan menentukan kriteria-kriteria yang akan dijadikan acuan dalam pengambilan keputusan, yaitu $\mathrm{Ci}$.

b. Membuat matriks perbandingan berpasangan

Membandingkan antar kriteria dalam bentuk matriks berpasangan dengan menggunakan skala kepentingan saaty untuk mendapatkan nilai eigen dan menguji konsistensirasio perbandingan (CR) dengan syarat konsistensi harus kecil dari 0.1 atau $\mathrm{CR}<0.1$.

Sebelum menentukan perbandingan matriks berpasangan antar kriteria, terlebih dahulu harus menentukan intensitas kepentingan masing - masing kriteria untuk menghindari CR $>0.1$ atau tidak konsisten. 
Tabel 1. Kriteria

\begin{tabular}{|c|l|c|}
\hline No & \multicolumn{1}{|c|}{ Kriteria } & Simbol \\
\hline 1 & Pekerjaan & C1 \\
\hline 2 & Penghasilan & C2 \\
\hline 3 & Konsumsi Gizi & C3 \\
\hline 4 & $\begin{array}{l}\text { Sumber } \\
\text { Penerangan }\end{array}$ & C4 \\
\hline 5 & $\begin{array}{l}\text { Kemampuan } \\
\text { Berobat }\end{array}$ \\
\hline
\end{tabular}

Tabel 2. Matriks Perbandingan Berpasangan

\begin{tabular}{|c|c|c|c|c|c|}
\hline & $\mathrm{C} 1$ & $\mathrm{C} 2$ & $\mathrm{C} 3$ & $\mathrm{C} 4$ & $\mathrm{C} 5$ \\
\hline $\mathrm{C} 1$ & 1 & 3 & 5 & 7 & 9 \\
\hline $\mathrm{C} 2$ & 0.33 & 1 & 3 & 5 & 7 \\
\hline C3 & 0.20 & 0.33 & 1 & 3 & 5 \\
\hline C4 & 0.14 & 0.20 & 0.33 & 1 & 3 \\
\hline C5 & 0.11 & 0.14 & 0.20 & 0.33 & 1 \\
\hline Jumlah & $\mathrm{C} 1$ & $\mathrm{C} 2$ & $\mathrm{C} 3$ & $\mathrm{C} 4$ & $\mathrm{C} 5$ \\
\hline
\end{tabular}

Diperoleh :

1. Nilai perbandingan untuk dirinya sendiri bernilai 1 yang berarti intensitas kepentingannya sama.

2. Perbandingan $\mathrm{C} 1$ dengan $\mathrm{C} 2$ bernilai 3 berdasarkan ketentuan saaty bahwa $\mathrm{C} 1$ sedikit lebih penting dari pada $\mathrm{C} 2$. Maka perbandingan $\mathrm{C} 2$ dengan $\mathrm{C} 1$ adalah cerminan dari perbandingan $\mathrm{C} 1$ dengan $\mathrm{C} 2$ yang berarti $1 / 3=0.33$

3. Perbandingan $\mathrm{C} 1$ dengan $\mathrm{C} 3$ mendapat nilai 5 yang berarti $\mathrm{C} 1$ lebih penting dari $\mathrm{C} 3$, dan perbandingan $\mathrm{C} 3$ dengan $\mathrm{C} 1$ cerminan dari perbandingan $\mathrm{C} 1$ dengan $\mathrm{C} 3$ yang berarti $1 / 5=0.2$

4. Perbandingan $\mathrm{C} 1$ dengan $\mathrm{C} 4$ mendapat nilai 7 berarti $\mathrm{C} 1$ sangat penting dari $\mathrm{C} 4$, dan perbandingan $\mathrm{C} 4$ dengan $\mathrm{C} 1$ cerminan dari perbandingan $\mathrm{C} 1$ dengan $\mathrm{C} 4$ yang berarti $1 / 7=0.14$

5. Perbandingan $\mathrm{C} 1$ dengan $\mathrm{C} 5$ mendapat nilai 9 yang berarti $\mathrm{C} 1$ mutlak lebih penting dari $\mathrm{C} 5$, dan perbandingan C5 dengan C1 cerminan perbandingan C1 dengan C5 yang berarti $1 / 9=0.11$

Setelah mendapatkan nilai perbandingannya, maka setiap nilai akan dibagi dengan hasil dari penjumlahan kolomnya, Tabel 3.

Tabel 3. Nilai Matriks Perbandingan Berpasangan

\begin{tabular}{|c|c|c|c|c|c|c|}
\cline { 2 - 7 } \multicolumn{1}{c|}{} & C1 & C2 & C3 & C4 & C5 & Eigen \\
\hline C1 & 0.5 & 0.6 & 0.52 & 0.4375 & 0.36 & $\mathbf{0 . 4 7 9 5}$ \\
\hline C2 & 0.1667 & 0.2141 & 0.3 & 0.3125 & 0.28 & $\mathbf{0 . 2 5 1 8}$ \\
\hline C3 & 0.1 & 0.0667 & 0.1 & 0.1875 & 0.2 & $\mathbf{0 . 1 3 0 8}$ \\
\hline C4 & 0.0715 & 0.04 & 0.0333 & 0.0625 & 0.12 & $\mathbf{0 . 0 6 5 5}$ \\
\hline C5 & 0.0556 & 0.0286 & 0.02 & 0.0208 & 0.04 & $\mathbf{0 . 0 3 3}$ \\
\hline Jumlah & 1 & 1 & 1 & 1 & 1 & $\mathbf{1}$ \\
\hline
\end{tabular}

Tampilan sistem yang dihasilkan :

a. Tampilan Halaman Menu Utama

Menu utama adalah halaman yang yang akan kita lihat ketika login berhasil dilakukan. Halaman ini berisi header sebagai judul halaman, nama sistem, serta menu-menu yang bisa kita pilih dan digunakan.

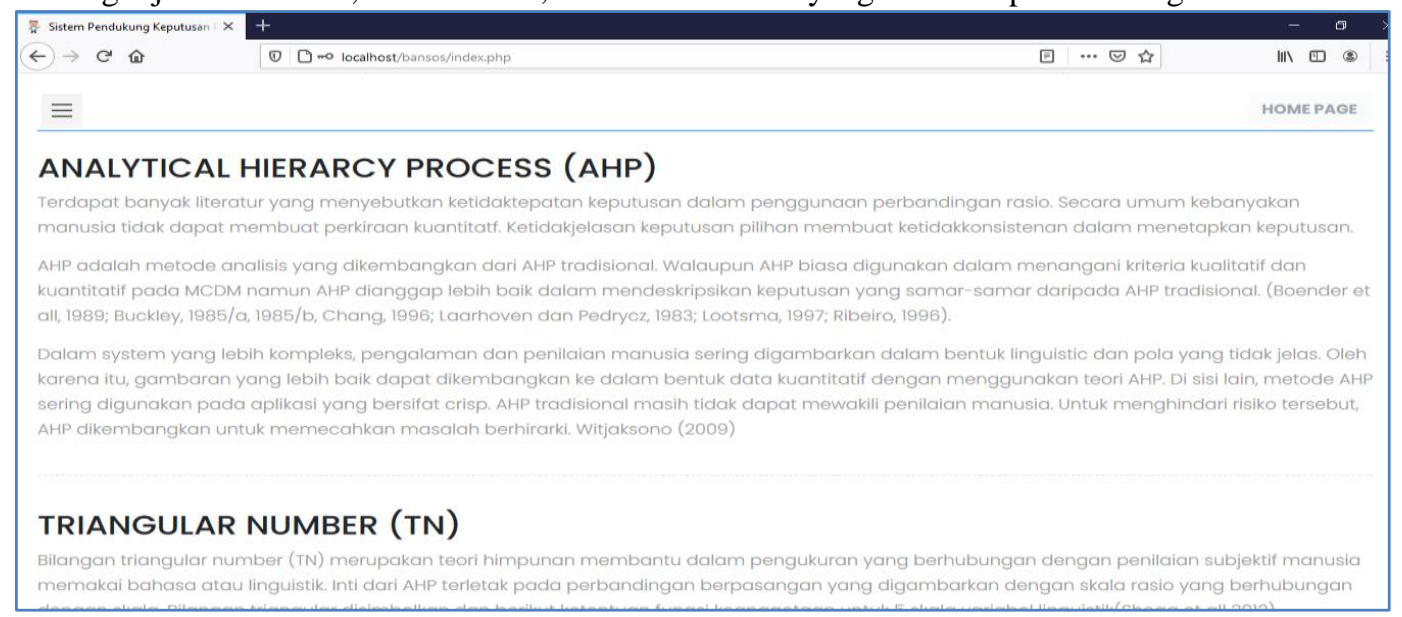

b. Tampilan Menu Peraangkingan

Gambar 1. Halaman Utama 
Pada tampilan menu perangkingan akan diketahui siapa yang layak untuk menerima pemberian bantuan.

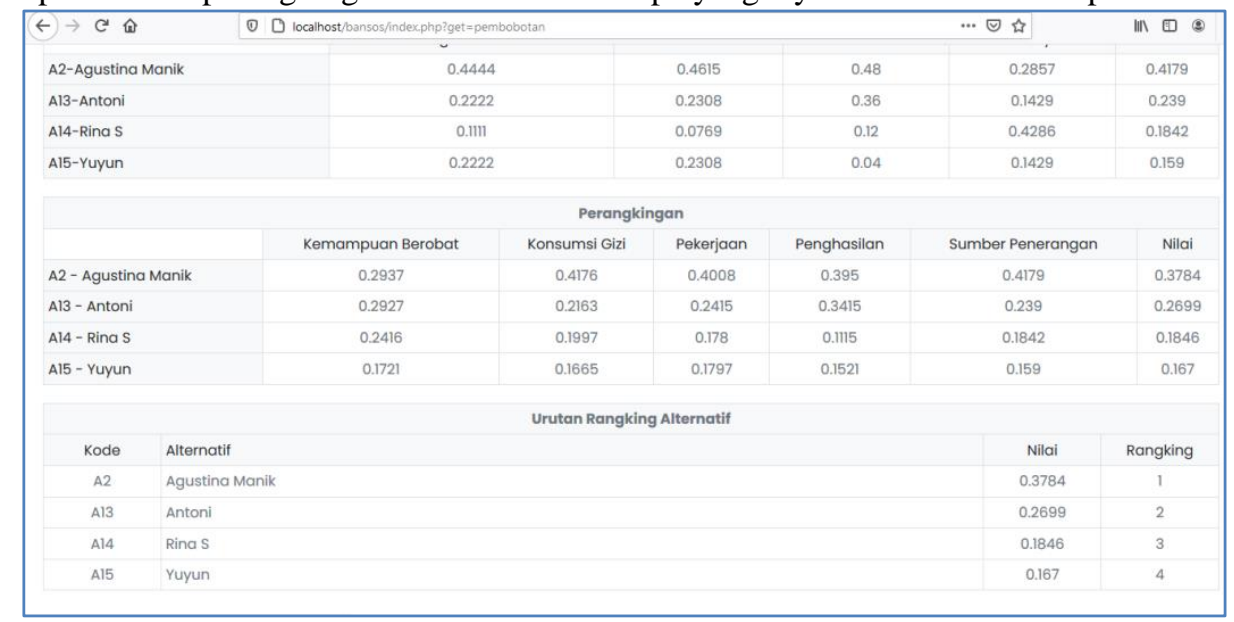

Gambar 2. Tampilan Menu Perangkingan

\section{Kesimpulan}

Kesimpulan dari penelitian :

1. sistem pendukung keputusan ini dibuat dapat membantu pengguna untuk mengetahui tentang pemberian bantuan yang dialami berdasarkan kriteria-kriteria yang ditentukan oleh ahp

2. sistem pendukung keputusan pemberian bantuan kepada keluarga tidak mampu berhasil diterapkan dengan menggunakan metode ahp dalam proses inferensi berdasarkan aturan yang dibuat oleh ahp.

3. penelitian ini telah menghasilkan sistem pendukung keputusan pemberian bantuan kepada keluarga tidak mampu menggunakan metode ahp berdasarkan kriteria kriteria sehingga didapat hasil perangkingan yang berhak menerima bantuan.

\section{Daftar Pustaka}

[1] L. Situmorang and J. R. Sagala, "Sistem Pendukung Keputusan Pemilihan Tentor Terbaik Dengan Metode Technique For Order Preference By Similarity To Ideal Solution (Topsis)," J. Nas. Komputasi dan Teknol. Inf., vol. 3, no. 3, pp. 209-214, 2020.

[2] R. Agusli, M. I. Dzulhaq, and F. C. Irawan, "Sistem Pendukung Keputusan Penerimaan Karyawan Menggunakan Metode AHP - Topsis," vol. 2, no. 2, pp. 35-40, 2020.

[3] N. Aminudin, I. Ayu, and P. Sari, "Sistem Pendukung Keputusan (Dss) Penerima Bantuaprogram Keluarga Harapan (Pkh) Pada Desa Bangun Rejo Kec.Punduh Pidada Pesawaran Dengan Menggunakan Metode Analytical Hierarcy Process (Ahp)," J. TAM ( Technol. Accept. Model ), vol. 5, no. 2, pp. 66-72, 2015.

[4] Z. K. Dunggio, F. Suleman, B. Senung, and F. Yuliani, "Sistem Pendukung Keputusan (Spk) Penerima Bantuan Program Keluarga Harapan (Pkh) Pada Desa Dulukapa Kecamatan Sumalata Timur Kabupaten Gorontalo Utara Menggunakan Metode Analytical Hierarchy Process (Ahp)," J. Inform. Upgris, vol. 6, no. 1, pp. 61-65, 2020.

[5] U. J. Ghafur, B. Dana, R. T. Miskin, A. Pendahuluan, and P. Indonesia, “http://journal.unigha.ac.id/index.php/JRR,” vol. 2, no. 2, pp. 97-107, 2020.

[6] M. Hidayat, "Penentuan Pemberian Bantuan Program Keluarga Harapan Dengan Metode Topsis," J. Penelit. dan Pengabdi. Kpd. Masy. UNSIQ, vol. 5, no. 1, pp. 98-106, 2018.

[7] M. A. H. P. K-means, "Sistem Pendukung Keputusan Penerima Bantuan Langsung Tunai Tepat Sasaran Menggunakan," vol. 3, no. 2, pp. 45-54, 2020.

[8] D. Lestari and A. S. R. Sinaga, "Penentuan Karyawan Kontrak Menjadi Karyawan Tetap PT. Timbang Deli Dengan Metode Analitycal Hierarchy Process (AHP)," J. Teknol., vol. 8, no. 2, pp. 27-37, 2018.

[9] A. A. Maulana and N. S. Hidayat, "Sistem Pendukung Keputusan Penentuan Penerima Bantuan Keluarga Miskin Menggunakan Metode Analytical Hierarchy Process - Technique For Order Of Preference By Similarity To Ideal Solution ( AHP - TOPSIS )," J. Pengemb. Teknol. Inf. dan Ilmu Komput. Univ. Brawijaya, vol. 2, no. 10, pp. 3890-3898, 2018.

[10] A. S. R. Sinaga and J. Purba, "Penentuan Karyawan Lembur Dengan Metode Analytical Hierarchy 
Process ( Ahp )," vol. 1, no. 2, pp. 40-50, 2018.

[11] S. Supriatin, B. S. Wiraatmadja, and E. T. Luthfi, "Sistem Pendukung Keputusan Untuk Menentukan Penerima BLSM Di Kabupaten Indramayu," Creat. Inf. Technol. J., vol. 1, no. 4, p. 282, 2015.

[12] E. Wiyanti and A. Sindar, "Implementasi Analytical Hierarchy Process dalam Menentukan Tingkat Kepuasan Pelayanan E-ktp (Studi Kasus Kantor Camat Pagar Merbau)," J. Nas. Komputasi dan Teknol. Inf., vol. 1, no. 2, 2018. 